\title{
МУЗИКА ЯК ОДИН З ВИХІДНИХ ЧИННИКІВ СТАНОВЛЕННЯ РЕЖИСЕРСЬКОГО МИСТЕЦТВА ВС. Е. МЕЙЄРХОЛЬДА
}

\begin{abstract}
Простежено режсисерські експерименти Вс. Е. Мейєрхольда периого періоду творчості. Артикульовано положення, щуо лягли в основу його режисерського методу, а також пошуки базових режисерських прийомів з відпрацювання принщипів умовного театру. Наголошено, щзо одним з вихідних чинників формування його режисури стає музичне мистецтво.
\end{abstract}

Ключові слова: режисер, умовний театр, музичне мистецтво, контрапункт, процессуальность, ритм, пауза, актор.

Прослежены режиссёрские эксперименты Вс. Э. Мейерхольда первого периода творчества. Артикулированы положения, которые легли в основу его режиссёрского метода, а также поиски базовых приёмов по отрабатыванию принципов условного театра. Подчеркнуто, что одним из исходных факторов формирования его режиссёрского искусства становится музыкальное искусство.

Ключові слова: режиссёр, условный театр, музыкальное искусство, контрапункт, прочессуальность, ритм, пауза, актер.

The director's experiments of Vs. Meyerhold the first period of creativity are traced. Articulated position, which formed the basis of his directorial method; the searches for basic techniques for working out the principles of a conventional theater. It is emphasized that one of the initial factors is the formulation of his director's art become musical art.

Key words: director, conditional theatre, musical art, counterpoint, procedurality, rhythm, pause, actor.

Значна роль в оновленні засобів сценічної виразності належить Вс. Е. Мейєрхольду, театральні ідеї котрого не втратили своєї актуальності й у XXI столітті. Початок його активної режисерської діяльності - початок XX ст. - припадає на період надзвичайно серйозних і суттєвих змін, які визначалися революційними потрясіннями. Цей був час інтенсивних пошуків і в галузі художньої творчості, адже «... різке розширення всього світу соціальних відносин» продемонструвало, «що побутова картина світу лише у певних масштабах здатна давати уявлення про об'єктивну реальність» [8, 222-223]. Для театрального мистецтва викликом ставало відпрацювання зовсім інших принципів театральної виразності, інших співвідношень сцени і дійсності. Не випадково, саме у театрі та літературі завдання втілення нового змісту, поза побутовими смислами проявляється найбільш конкретно й явно.

Центральним явищем, що визначило естетичний зміст початку XX ст. та сприяло виникненню принципово нових театральних форм, стала драматургія А. П. Чехова. Чеховські «підводна течія», підтекст, «другий план», який містив справжній зміст драми та був частиною ліричного «музично організованого потоку», [14, 124], провокували виникнення «фізичного» відчуття плинності часу, який, своєю чергою, створював «фізичне» відчуття музики, зачаровуючи глядачів «саме видовищем і музикою повсякденної течії життя» $[3,157]$. Особливість драматургії А. П. Чехова передбачала обов'язкову єдиноначальність у підготовці вистави. Віднині художня єдність спектаклю передбачала змістовну функцію всіх компонентів п'єси. Новий тип драми спонукав до виникнення нового типу художньо-організаційних зв'язків вистави, де головною постаттю ставав режисер. Драматургія А. П. Чехова відкрила для Мейєрхольда нові естетичні горизонти і підштовхнула до відпрацювання відповідних засобів виразності. Режисер бачив шлях створення «Нового театру» через ліричний талант музичного Чехова» $[11$, т. 1, 123], 
але, на відміну від своїх учителів, він намагався відійти від показу життєподібності у відображенні побуту. Мейєрхольд прагнув до «Театру настрою», де «Влада Тайни» стала б не лише художньою недомовкою, а й заплутаністю внутрішніх стосунків людей. Підтвердження своїм пошукам він знаходив у словах А. П. Чехова стосовно того, що «сцена $<\ldots>$ вимагає певної умовності» i «відображає у собі квінтесенцію життя» [11, т.1, 120]. Аналізуючи «Вишневий сад», Мейєрхольд стверджував, що у цій «драмі Чехова, як і у драмах Метерлінка, $є$ герой, котрий не видимий на сцені, але він відчувається щоразу, коли завіса опускається» [11, т. 1, 119].

Вс. Е. Мейєрхольд став тим режисером, котрий одним 3 перших пішов шляхом піднесення споконвічної умовності театрального мистецтва в основоположний естетичний принцип. Його цілеспрямований і принциповий шлях від реалізму до умовного театру визначався як новою системою образного мислення, що було характерно для мистецтва початку XX ст., так і індивідуальними особливостями його світовідчуття. Режисер вважав умовність неминучою у театрі, а «намагання хоч що б там стало показати все, острах тайни, недомовленості перетворює театр у ілюстрування слів автора» $[11$, т. 1, 120]. Проте умовний метод, на думку Мейєрхольда, здатен у сконцентрованому образі передати істинний смисл буття, надає можливість режисерові проникнути за межу відчутного світу і виявити потенційний сенс явищ, тобто розкрити їх справжню сутність.

Драматургія А. П. Чехова підштовхнула Мейєрхольда до застосовування законів музичного мистецтва у режисурі. Зокрема, режисерське рішення третього акту «Вишневого саду» $з$ метою максимально повного виявлення його внутрішньої сутності він бачив у такий спосіб : «Всі навколо живуть якось тупо: ось задоволені - вони танцюють під монотонне побрязкування єврейського оркестру i, як у кошмарному вихорі, кружляють у нудному сучасному танці, в якому немає ані захоплення, ані азарту, ані грації, ані навіть хіті, - не знають, що земля, на якій вони танцюють, зникає 3-під ніг. Лише Раневська передбачає біду й чекає iii, і метушиться, i на хвилину зупиняє колесо, що рухається, цей танок маріонеток у їхньому балаганчику... Якщо перевести на музичну мову, це одна 3 частин симфонії. Вона містить у собі: основну тужливу мелодію зі змінними настроями в pianissimo і спалахами в forte (переживання $\mathrm{Pa}$ невської) і тло - дисонантний акомпанемент - однотонне брязкання закуткового оркестру і танок живих трупів (обивателів). Ось музична гармонія акту» $[11$, т. 1,118$]$.

Відкриття внутрішньої музикальності чеховських п'єс дало змогу Мейєрхольдові виокремити формоутворюючу функцію музики у сценічному втіленні режисерської концепції. Вже на ранньому етапі режисерської діяльності його пошуки художньої цілісності вистави були пов'язані 3 прагненням знайти у іiї композиції відповідність законам побудови твору музичного, зокрема сонатно-симфонічного циклу. Мейєрхольд був переконаний, що «компонувати спектакль потрібно за всіма правилами оркестрової композиції, $<$.. > Партія актора кожна окремо ще не звучить, потрібно іiі обов'язково ввергнути в масу груп інструментів-ролей, сплести цю групу в дуже складну оркестровку <...> Якщо режисер не музикант, - вважає Мейєрхольд, - то він не зможе побудувати справжню виставу <..> Ціла низка труднощів неподоланні лише тому, що не знають як підійти до речі, як іiі музично розкрити» [11, т. $2,140,156-157]$. Без цього міркування вже зрілого Мейєрхольда навряд чи можна достатньо точно зрозуміти значення його експериментів раннього періоду, періоду формування концепції умовного театру. Саме це прагнення до композиційної стрункості й точності гармонійних поєднань через взаємодію різних тематичних пластів, до процесуальності розвитку основних тем, динамічне нюансування, музичний ритм тощо змушує режисера постійно звертатися до законів симфонічної музики. У розмовах із студентами режисерських курсів він неодноразово зазначав, що музика $\epsilon$ «найдосконалішим мистецтвом», і навертав майбутніх майстрів сцени частіше відвідувати симфонічні концерти, при цьому, «слухаючи симфонію думати про театр $<\ldots>$ Зміна контрастів, ритмів і темпу, поєднання основної теми з побічною - все це так само необхідне у театрі, як і у музиці. Композиційне розв'язання музичних творів нерідко може допомогти вам знайти якісь композиційні принципи розв'язання вистави» [11, т. 2, 506]. У прагненні до мистецтва великих узагальнень, до «надпобутового» театру Мейєрхольд пропонував використовувати закони симфонічної музики як структуруючий чинник у побудові вистави.

Характерне для театру Чехова перенесення акцентів $з$ дії зовнішньої на дію внутрішню було використане Мейєрхольдом у розробці ідей «Нерухомого театру», де сценічний драматизм здобувався шляхом внутрішньої емоційної концентрації при зовнішній статичній пластиці. Пластичний малюнок кожної ролі, будь-який сценічний 
рух мислився як «музика пластичних рухів», яка має дати зовнішній малюнок внутрішнього переживання. За Мейєрхольдом, «техніка "Нерухомого театру" надає перевагу скованості жесту й економії руху жесту загального місця». Техніка такого театру, стверджує Мейєрхольд, «боїться» зайвих рухів, аби не відвертати увагу глядача від складних внутрішніх переживань [11, т. 1, 125]. У зв'язку з цим істотно посилюється роль музичної складової у виставі, яка мала виконувати функцію змістовного контрапункту. У «Нерухомому театрі» музика не претендувала на відповідність психологічному станові героя, і взагалі, Мейєрхольд мав на увазі не лише музику, що звучить у виставі, а й іiі невербальні можливості у їі побудові, котрі були б спроможні позначити те, що стоїть на протилежному боці конфліктної межі. Особливо наочно він висловлює це у листі до А. П. Чехова щодо постановки у МХТ «Вишневого саду»: «Ваша п’єса абстрактна, як симфонія Чайковського. I режисер повинен вловити іії слухом насамперед. У третьому акті на тлі глупого «тупотіння»ось це «тупотіння» треба почути - непомітно для людей входить «Жах»: «Вишневий сад продано». Танцюють. «Продано». Танцюють. I так до кінця. Веселощі, в яких чутні звуки смерті. В цьому акті $\epsilon$ дещо метерлінківське, страшне. В Художньому театрі від третього акту не залишається такого враження. Тло мало згущене <..> люди танцюють і не відчувають біди <..> У МХТ вкрай повільним $є$ темп цього акту. Хотіли зобразити нудьгу. Помилка. Потрібно зобразити безтурботність $<\ldots>$ Тоді трагізм акту сконцентрується» $[11$, т. 1 , 85-86]. Таким чином, режисерське моделювання цілого шляхом одночасного виявлення конфлікту змістовних тем (мотивів) через застосування специфіки музичного формоутворення певною мірою визначає вихідні точки мейєрхольдівського методу.

Теоретичне обгрунтування i практичне засвоєння постановницьких принципів «Умовного театру» неминуче приводять Мейєрхольда до стилізації, яка, відзначає він, невід'ємно пов'язана 3 ідеєю споконвічної театральної умовності й виникла на початку XX ст. як необхідність «вивести акторів 3 анархії натуралістичного театру» [11, т. 2, 40]. Вперше принцип стилізації, що передбачав максимально повне використання можливостей сценографічного і музичного мистецтв, був застосований режисером під час роботи над постановкою п’єси Г. Гауптмана «Шлюк і Яу» в Студії на Поварській (1905). Під стилізацією Мейєрхольд розумів не точне відтворення стилю даної доби, а виявлення всіма засобами виразності внутрішнього синтезу епохи або явища: «відтворити приховані характерні їхні риси, які бувають у глибоко прихованому стилі будь-якого художнього твору» $[11$, т. 1,109$]$. Стійкий інтерес до музичного начала проявився й у пошуках режисерського рішення «стилізованих» вистав Вс. Мейєрхольда. 3 одного боку, посилюється емоційно-змістовна роль музики, 3 іншого - набуває нового значення ii формоутворююча функція. У цих виставах музика стає наче камертоном, що визначав стрункість усіх компонентів вистави. Він стає одним 3 перших, хто стосовно сценографічного рішення вистави вводить поняття тональної співзвучності і тонального контрасту за принципом тонально-тематичної залежності у музичному мистецтві. За Мейєрхольдом, вся «побудова» вистави має бути «суворо підкорена ритмічному руху ліній і музичній співзвучності колоритних плям» [11, т. 1, 135].

Якщо у прагненні до візуальної гармонії та цілісності сценічної дії у постановці «Шлюка і Яу» Мейєрхольд доволі легко знайшов форму підкорення живописно-музичного боку вистави загальному режисерському завданню, то значно складніше було вирішити аналогічне завдання в роботі з актором. Найбільш загальною вимогою в галузі акторського виконання стали для нього ритм і «музичність». Він акцентував, що «актор працює за партитурою, даною йому режисером, партитурою чітко вивіреною і точно розрахованою. Найменше відхилення у будь-якій частині завданої партитури тягне за собою руйнацію композиційної цілісності спектаклю» [11, т. 2, 262]. Досягти цієї гармонії, за переконанням Мейєрхольда, може лише музично і пластично підготовлений актор, адже його «рухи, його мова мають бути пронизані музикою» [10, т. 1, 284]. Можливо, це не вирішувало проблеми акторського виконання в цілому, але було неодмінною вимогою акторської техніки умовного театру, вважав режисер.

Наступним кроком відпрацювання принципів умовного театру у творчості Вс. Е. Мейєрхольда стала його робота в Театрі на Офіцерській, коли він захоплювався символізмом, найбільш впливовою течією модерного театру початку ХХ ст. Слід зазначити, що умовний театр, як своєрідний тип художнього мислення, i символізм мали багато спільного. У філософському обгрунтуванні символізму людина уявлялася як замкнена, самодостатня система, яка існувала за законами власного духовного світу. Оточена незрозумілим, чужим середовищем, людина цурається його як такого, що $\epsilon$ обивательським і здійснює пагубний вплив на 
високі духовні устремління. Таким чином, предметом мистецтва ставала душа людини, а не реальний світ, в якому вона мешкає, а значення митця визначалося тим, наскільки глибоко він «зрозумів і переказав свою душу» [4, 45]. Основою розуміння світу стає пізнання митцем уявлення про нього, а отже виникає не аналітично-логічна, а інтуїтивно-особистісна система проникнення у сутність світу, здатна відхилити завісу над таїною буття. Світ у символістів наче втрачав свою реальну конкретність й починав існувати у сприйнятті тієї чи іншої людини, котра до нього доторкалася. Такий спосіб пізнання дійсності і зближував завдання умовного театру і символізму.

Умовність розглядалася символістами як природна властивість театру. Маніфест символізму в галузі сценічного мистецтва - стаття одного 3 теоретиків символізму В. Брюсова «Правда, яка не потрібна», - надав теоретичну основу «новому мистецтву», котре давно вже почало обтяжуватися фотографічною копією дійсності, що пропонувалася театром натуралістичним. Оскільки предмет мистецтва - душа митця, то правда уречевленого побуту, що заступила собою «потрібні» аспекти правди, є хибною. У маніфесті наголошено, що «відтворити правдиво життя на сцені неможливо» $[4,69]$, оскільки «сцена за своєю сутністю умовна» $[2,170]$.

Для символістів «музика - душа всіх мистецтв» і твори всіх мистецтв оцінюються мірою ïx наближення до «духу музики» $[2,179]$, зокрема у театральному мистецтві - музика максимальним чином «допоможе глядачу в найлегший спосіб відновити в уяві обстановку, що закладена у фабулі п'єси» $[4,72]$. Прагнення до символічної складності і злиття різних видів мистецтва породило симфонії О. Скрябіна і живописні «сонати» М. Чюрльоніса, котрий передавав текучість і рух музики в звучності кольору. Особливо наочно це простежується у художній практиці поеті-символістів. Вони намагалися застосувати до літератури принцип музичної композиції. У поетичних симфоніях лідера символізму А. Білого теми розгорталися не логічним розвитком думки, не ходом фабульної дії, а через розвиток декількох словесних лейтмотивів, їхнього зіставлення, варіювання, повторення на кшталт розвитку тем у симфонічній музиці. Поезія символістів будувалася за принципом ритмічної реорганізації вірша з висуненням музичного боку. Вяч. Іванов у «музичному присмерку» бачить те, «що немислиме при гнівному світлі слова» $[6,174]$. Для А. Білого - це «вікно, 3 якого ллються у нас чарівні потоки Вічності й бризкає магія» $[2,225]$. У художніх концепціях О. Блока сама історія перетворюється на музичний потік. Спираючись на філософію А. Шопенгауера і Ф. Ніцше, теоретики символізму вважали, що музика стоїть над усіма іншими мистецтвами і якоюсь мірою їх визначає; що музика найбільш повно охоплює всі сфери буття і духу, вбираючи у себе можливості та засоби виразності всіх інших мистецтв.

Вс. Е. Мейєрхольд, так само, як символісти, розумів, що оновлення театру пов'язане з розширенням конструктивної ролі музики. Він продовжує шукати загальні закономірності у підході до рішення спектаклю шляхом привнесення принципів музичної композиції, пропонуючи принцип поліфонічного співіснування тем і основних лейтмотивів, домагаючись процесуальності сценічної дії за аналогією з музикою. Горизонтальний розвиток тем на сцені набував ще й вертикального виміру, що привносився музикою. Драматична тема сценічної дії продовжувала свій розвиток у темі музичній, чим забезпечувала безперервність іiї існування (або розвитку) протягом усієї вистави. Вперше такий прийом був використаний режисером при постановці «Сестри Беатріси» М. Метерлінка у Театрі на Офіцерській (1906), коли музика відновлювала символ - статую Діви, - що зникав зі сцени.

В період захоплення символізмом Вс. Мейєрхольд експериментує з функціональними можливостями музичного мистецтва, зокрема 3 реалізацією мотиву двійників у виставі «Балаганчик» О. Блока (Театр на Офіцерській, 1906). Мотив подвійності світу був вельми характерним для творчості символістів. О. Блок відчував іiї як хворобу сучасності «кожної людської душі, яку потрібно перемагати» $[12,598]$. Саме у зв'язку з цим одним 3 найважливіших мотивів творчості символістів стає тема протиставлення світу сутності, який пізнається лише засобами мистецтва, і світом видимості, який є доступним усім. Цим пояснюється значущість поняття маски як поняття закритості сутності, невпізнанності ії та відчуття світу як трагічного балагану. Не випадково Вс. Мейєрхольда так зацікавив «Балаганчик», де панують принцип вивільнення від маски, пошуки цілісного, що його не можна розкласти, не маскарадного у житті й людині. Але театралізована, пустотлива гра вимагала опори на справжне, в інакший спосіб все могло знецінитися. У суцільному маскараді, де одна маска змінюється іншою, а друга - третьою, людина могла і не відшукати власного обличчя. Як нерозкладну цінність, споконвічну якість душі 
Мейєрхольд услід за О. Блоком виявляв у своєму «Балаганчику» ліричне начало, яке живе у П'єро, його музичне, художнє ставлення до світу.

Задля втілення теми двоїстості світу Мейєрхольд відпрацьовує новий прийом, що посилював поліфонізм його режисерського рішення, - гротеск, і знов шукає його втілення через музику, роль якої у виставі значно ускладнюється. «Гротеск, - відзначає режисер, - зумів покінчити всілякі рахунки з аналізом. Його метод суворо синтетичний. Гротеск, без компромісу зневажаючи всілякими дрібницями, створює (в умовній неправдоподібності) всю повноту життя» [11, т. 1, 225]. Музика, що звучала у «Балаганчику», була водночас і маскою на «обличчі» вистави, і тим ліричним началом, яке напосідливо пробивалося крізь цю маску, відкриваючи істинну сутність людської душі. Отже, важливий для сценічного гротеску мотив підміни, який був спроможним раптово «вивести глядача з одного, щойно осягненого ним плану, в інший, що його глядач жодним чином не очікував» [11, т. 1, 227], успішно використовувався і вирішувався Мейєрхольдом за допомогою музики, яка і відкривала «тонкому спостерігачеві таємничі натяки» [11, т. 1, 229], показуючи справжне і безсумнівне у житті.

Гротеск не лише як художній прийом, а й як система світогляду, неможливий без контрасту, проте сам Мейсрхольд рішуче заперечував наявну думку, що «гротеск покликаний лише як засіб створювати контрасти або їх встановлювати» [11, т. 1, 226]. Для нього це не прямолінійне протиставлення протилежностей, а їх одночасне «врівноважене» співіснування. Розуміння режисером гротеску на даному етапі максимально зближувалося з тлумаченням поняття «романтична іронія», як О. Блока, так і німецьких романтиків, зокрема, А. Шеллінга та Л. Тіка, котрі вважали це системою об'єднання нез'єднаного, переходу з однієї площини сприйняття в іншу, поєднання світу реального 3 ірреальним, внаслідок чого створювалося те магічне коло гри, з якого виростало саме життя. I хоча контраст - поняття загальне для всіх видів мистецтва, Мейєрхольд використовує його саме за принципом музичного контрасту, коли розвиток якоїсь однієї теми виявляє в процесі розвитку непримиренні суперечності, але розділити i протиставити їх не можна, оскільки зникнуть повнота і цілісність даної теми, порушиться процесуальність їі розвитку. У цьому і полягає «завдання сценічного гротеску, щоб постійно тримати глядача у стані того двоїстого ставлення до сценічної дії, що змінює свій рух контрастними штриха- ми» [11, т. 1, 226-227]. Використання принципу контрастуа надавало режисерові можливість поглиблювати перспективу драматичного сюжету, розчленовувати різні плани театрального образу, змішувати їх, зіштовхувати між собою, досягаючи створення сценічного життя в його особливих часових і просторових вимірах.

Починаючи з 1908 р., після відходу з Театру на Офіцерській, Мейєрхольда починають дедалі більше захоплювати форми допрофесіонального театру. Вивчення прийомів іспанського та італійського народних майданових театрів мало надзвичайний вплив на подальше формування його режисерської естетики. Художнє осмислення, а почасти переосмислення прийомів допрофесіонального театру, вміння їх трансформувати $\mathrm{i}$ стало тим інструментом, який дав йому пізніше можливість віртуозно реалізувати систему стилізації як основний режисерський прийом. Замість сценічної статики, приглушених голосів, скульптурних мізансцен у наступних постановках 3'явилися бурхливі рухи, масові танці, імпровізації. Подальша робота Мейєрхольда з розширення виражальних можливостей театру пов'язана зі зверненням до класичної спадщини. Новий напрям його режисерських шукань 1908-1917 pр. відбувається в межах програми театрального традиціоналізму, яка, за його задумом, передбачала створення сучасного сценічного видовища на основі використання різноманітних форм умовного театру, всього його досвіду, завдяки чому режисер намагався відтворити стиль театру минулих часів. Визнаними досягненнями Мейєрхольда у цьому напрямі були постановки в Маріїнському («Тристан та Ізольда» Р. Вагнера, «Орфей Х.-В. Глюка) і Александрінському («Дон Жуан» Ж. Б. Мольєра, «Гроза» О. Островського, «Маскарад» М. Лермонтова) театрах, а також низка пантомім у Домі інтермедій («Шарф Коломбіни» А. Шніцлера на музику Е. Донаньї, «Арлекін адвокат весіль» В. Люсциніуса на музику Гайдна і Арайя) та у Групі пантоміми з воскресіння техніки старовинних театрів («Закохані» на музику К. Дебюссі).

Реалізація програми театрального традиціоналізму приводить Мейєрхольда до ідеї сценічного контрапункту (у цей період у режисерській роботі Мейєрхольда продовжується відпрацювання прийому сценічного контрапункту). У своїх режисерських рішеннях він вільно використовує різні сценічні плани, сміливо перемикає дію від однієї сюжетної лінії до іншої, при цьому не перериваючи розроблення попереднього сценічного плану. 
Одночасне сценічне існування і розвиток двох або більше тем, що були передбачені режисерською концепцією, забезпечувалося функціональним співвідношенням пластичної і звукової складових вистави. Одна тема могла розвиватися через сценічну дію персонажів, інша - у контрапунктному викладенні проводилась у музиці або будувалася на складному переплетінні сценічної дії, музики, елементів тощо.

Проблема співвідношення слова, руху і музики спонукала Мейєрхольда звернутися до теоретичних опусів Ріхарда Вагнера, театральні та загально естетичні ідеї котрого викликали великий інтерес у художніх колах на початку XX ст. Спираючись на його теорію музичної драми, Мейєрхольд робить висновок: «Як у музичній драмі проспівана співаком фраза, так само і в драмі слово - недостатньо сильне знаряддя, щоб виявити внутрішній діалог. <..> проголошувати слова, навіть добра проголошувати їх, ще не означає сказати. Виникла необхідність випробувати нові засоби виразити недоказане, виявити приховане. Як Вагнер про душевні переживання дає говорити оркестру, так я даю про них говорити пластичним рухам». Але, уточнює режисер, ідеться не про пластику, що суворо узгоджена зі словами, котрі проголошуються, а про «пластику, що не відповідає словам» [11, т. 1, 135]. Мова і пластика актора у спектаклі умовного театру мають бути побудовані в такий спосіб, щоб сконцентрувати увагу на суттєвих моментах сценічного буття. Мейєрхольд вирішує цю проблему через контрапунктний зв'язок слова і руху, констатуючи при цьому, що це $\epsilon$ «вкрай складною річчю» $[11$, т. 2, 156]. У зв'язку 3 цим він вважав своїм завданням надати рухам і позам акторів такого малюнка, щоб це допомагало «глядачу не лише слухати їхні слова, а й проникати у внутрішній прихований діалог». I якщо режисер, занурившись у «тему автора», почув музику внутрішнього діалогу, «він пропонує актору ті пластичні рухи, які <..> здатні змусити глядача сприйняти цей внутрішній діалог таким, яким його чує режисер і актори». За Мейєрхольдом, режисер має виявити приховані взаємовідносини персонажів у мізансценах, у невербальних засобах сценічної виразності. Він вважає, що «різниця між старим і новим театром та, що в останньому пластика і слова підкорені кожне своєму ритму, подеколи перебуваючи у невідповідності». Тому просторово-пластичне рішення спектаклю було орієнтоване на оголення внутрішнього діалогу (підтексту), на «розгадування душевних переживань дійових осіб» [11, т. 1, 135-136].
Вс. Е. Мейєрхольд розумів, що, окрім ретельної організації сценічного простору, не менш важливою $\epsilon$ й ретельна вивіреність сценічного часу. Захоплення пошуками засобів виразності, здатних передати рух часу на сцені, змушує його знов апелювати до законів музичного мистецтва, головними $з$ яких він вважав темпо-ритмічну організацію сценічного часу за аналогією з законами музичної композиції та прагнення передати відчуття процесуальності сценічної дії. У своєму прагненні привести у гармонійну відповідність усі складові спектаклю, Мейєрхольд відчував, що потрібно виявити дещо, що буде об'єднуючим началом, яке і надасть художню цілісність усій виставі. У процесі тривалих міркувань і численних студійних експериментів він доходить висновку, що таким началом може стати ритм як універсальна сила, що проявляється у всіх компонентах театрального дійства, ритм як споконвічна даність усіх видів мистецтва. Для Мейєрхольда ритм у всій його подальшій режисерській роботі став тією об'єднуючою домінантою, що зводила воєдино всі сценічні компоненти. Він констатував, що «ритм $є$ ритм. Можна все брати у цьому естетичному зовнішньому розрізі, раз і назавжди сказати, а потім не говорити. Ритм це $є$ ритм з усіма його особливостями, він проявляється назовні, але внутрішньо насичений якимись думками - інакше це не ритм» [11, т. 2, 452]. Розуміння ритму залишалося одним 3 основних формоутворюючих чинників у побудові вистави, адже режисер був упевнений, що «театр як видовищне дійство має отримати форму у ритмі, оскільки ритм є неодмінною умовою будь-якого мистецтва $<\ldots>$ А музика $є$ кульмінаційний пункт перемоги ритму. У музиці ритм знаходить свої закони і засоби свого відображення» $[1,22]$.

Проблема ритму стала майже ключовою точкою міркувань теоретиків і практиків мистецтва початку XX ст.. Вона хвилювала поетів, які досліджували закони ритмічної структури вірша. Ідея ритмічної пульсації музики захоплювала Айседору Дункан, палким прихильником якої був Мейєрхольд. Через пульсацію ритму музичного твору Дункан надавала йому пластичної інтерпретації. Передача ритмічного візерунка музики, екстатичне захоплення руху під музику й були основою іiі творчості. Великий інтерес виявляв Мейєрхольд і до системи Жака Далькроза, який в обгрунтуванні своєї ритмопластичної теорії спирався на музичне мистецтво. Згідно з Далькрозом, у кожної людини свій ритм. Тому першою умовою творчості є здатність перейняти чужий ритм. I якщо А. Дункан це «Я», що танцює, то 
у Ж. Далькроза - це музика, що танцює [5, 167]. У «ритмічному русі людського тіла у просторі» $[13,76]$ вбачає сутність драми Георг Фукс, котрий справив великий вплив на формування режисерської системи Мейєрхольда. Г. Фукс вважав, що, лише оволодівши ритмом, актор може хвилювати серця глядачів. Рухи тіла актора мають бути наближені до ритмічно організованої пластики танцівника, але не уподібнюватися їй повністю. Зрозуміти ритм життя - означає справді відкрити шляхи нового мистецтва, стверджував відомий на той час театральний критик О. Кугель, - $\mathrm{i}$ «великі митці завжди, в той чи інший спосіб, видобували 3 життя його ритм, надаючи можливість відчувати його словом. Але ритм видобувається не лише словом. Найближчим вираженням ритму є рух» $[7,171]$. Творчість балетмейстерів цього періоду, зокрема М. Фокіна, який займався проблемою відношення танцю до музичного ритму і з яким, на певному етапі своєї творчості, співпрацював і Мейєрхольд, - так само прояв пошуків загальної ритмічної єдності.

У річищі загальної зацікавленості проблемою ритму, Мейєрхольд визначав і завдання театрального мистецтва, стверджуючи, що театр, в якому діє «закон часовий» і «закон просторовий», вимагає від режисера «бути музикальним», «мати хороший слух», «вміти лічити час, не виймаючи годинника», а ритм «дає орієнтацію стосовно того, як потрібно розпоряджатися часом» $[11$, т. 2 , 272-273].

Поряд з виокремленням ритму як універсальної сили, Мейєрхольд прагне використовувати за аналогією й інші формоутворюючі закони музики у побудові вистави. 3 вирішенням ритмічної цілісності спектаклю нерозривно пов'язаний його інтерес до пауз і цезур, які використовувались ним як ефективні моменти у розвитку сценічної дії. Зупинка зовнішньої дії сприяла концентрації уваги на дії внутрішній, що забезпечувало безперервність сценічної дії в цілому. Наявність пауз, а також їх кількість і тривалість ретельно осмислювалася; паузи не були випадковими або штучно впровадженими у партитуру вистави. За суворими законами ритму, паузи органічно знаходили собі місце у сценічній тканині вистави, не руйнуючи логіки побудови дії і сприяючи максимальній змістовності у втіленні режисерського задуму.

Велику увагу Вc. Мейєрхольд приділяв розробленню мовної партитури вистави, яка мала включати інтонаційний лад мови актора, голосові модуляції, паузи та їх тривалість (аж до секунд), особливості тембрального звучання голосів.
Мейєрхольд шкодував, що в театрі не знайдено спосіб «синтетично збирати слова у своєрідну прозову мелодію» $[11$, т. 1,286$]$, фіксувати знайдену інтонацію і в потрібний момент з точністю їі відтворювати, на кшталт того, як це відбувається у музиці. Інтонаційно-мовна партитура розроблялася режисером у взаємозалежності з партитурою пластичною, але сценічне втілення розробленої режисером партитури багато в чому залежало від уміння актора їх реалізувати. «Я можу інструментувати партитуру лише разом з актором, 3 живим інструментом мого твору» $[11$, т. 2, 501], - відзначав Мейєрхольд. Звідси його прагнення до суворої фіксації зовнішнього малюнка кожної ролі. Якщо мова актора, зауважує режисер, складається з чергування слова і мовчання, то мова пластична 3 чергування руху і пози, тобто пластика актора, яка діє на зір, має максимально використовувати простір, а голос, який діє на слух, - таку категорію як час. Через це, на його думку, простір і час є невблаганними умовами, в які актор поставлений і 3 яких не може вийти, Завдання режисера співвиміряти, організувати, привести до загальної тональності і ритму пластичну і мовну складові вистави, знайти ритмічну супідрядність слова і руху.

Таким чином, відчуття і дотримання запропонованого режисером ритму стає моментом організації акторського виконання. Мейєрхольд із сумом зауважує, що він «досі стикається з акторами, які слово "ритм" вживають тоді, коли потрібно говорити “метр", і навпаки. Цю область актор повинен знати < ..> Що таке темп руху? Яка різниця між легато і стаккато? Адже якщо актор не розрізняє різниці метра і ритму, то він не знає різниці легато і стаккато» $[11$, т. 2, 152]. Проте Мейєрхольдові потрібен не «ритм метронома», а музичний ритм, оскільки «канвою руху завжди є музика, або реально існуюча у театрі, або така, що передбачається, така, що наче відспівується дійовою особою» [9, 62]. Вочевидь, режисерський підхід Мейєрхольда передбачав добре підготовленого актора, через що він і вимагав від актора «тих спеціальних знань теорії музики, того спеціального вивчення законів метра і ритму, які так необхідні Новому театрові» [11, т. 1, 238].

Для Мейєрхольда музика була значно більш широким поняттям, ніж просто елемент, фактор, навіть вид мистецтва. Вона була для нього своєрідним проявом пульсації життя (щоразу зі своїм ритмом, метром, нюансуванням, відтінками), тим, через що могло проявитися надпобутове.

Неодноразово, впродовж усього творчого шляху, він проголошував думку про «сувору від- 
повідність» між основною ідеєю і «внутрішньою музикою» твору [11, т. 1, 237]. Першочерговим завданням режисера при цьому було почути точний тон твору, визначити основну ідею і, відштовхуючись від цього, шукати адекватну форму його вираження, спираючись на закони музичного мистецтва, власне, створити композицію вистави. Вельми показовим $є$ таке його побажання молодим режисерам: «Коли почнете вивчати музичну форму, ви побачите, що багато спільного у побудові музичної форми 3 тим, як будується драматургічний матеріал; тому часто використовують вислів: вистава тричастна або чотиричастна. Це запозичене у музикантів <..> звідси вміння розв'язати питання щодо розбивання спектаклю на частини $<$...> Всі ці речі містяться в сфері музичної побудови вистави» [11, т. 2, 272-273]. Наступним етапом постановницької роботи режисера Мейєрхольд вважає «інструментовку створеної режисером музики-постановки» $[11$, т. 2, 502], коли відбуваються пошуки потрібного для втілення режисерського задуму темпо-ритму, точної інтонації, пластики, мізансцен, музичного оформлення.

Змінювалися погляди Вс. Е. Мейєрхольда на засоби сценічної виразності, змінювалися його естетичні, навіть філософські переконання, але звернення до музичного мистецтва залишалося незмінним пріоритетом у його режисерській роботі. Музика була для нього не лише формоутворюючим чинником, що само по собі було суттевим досягненням у галузі композиційної побудови вистави. Через формоутворюючі можливості музичного мистецтва Мейєрхольд ішов до створення цілісної системи театрального видовища, тієї органічної єдності, де форма стає змістом, а зміст будує форму.

\section{Джерела та література}

1. Архангельский А. Музыка и ритм сценического действия / А. Архангельский // Маски. - М., 1912-1913. - № 6.

2. Белый А. Арабески / А. Белый. - М. : Мусагет, 1911. $501 \mathrm{c}$.

3. Берковский Н. Я.Литература и театр : Статьи разных лет / Н. Я. Берковский. - М. : Искусство, 1969. - 639 с.
4. Брюсов Вал. Собр. соч. : в 7 т. / Валерий Брюсов. - М. : Художественная литература, 1975. - Т. 6. - 389 с.

5. Волконский С. Человек на сцене / Сергей Волконский. Спб. : Аполлон, 1912. - 182 с.

6. Иванов Вяч. Борозды и межи Опыта эстетические и критические / Вячеслав Иванов. - М. : Мусагет, 1916. - 244 с.

7. Кугель А. Р. Утверждение театра / А. Р. Кугель. - Л. : Театр и искусство, 1922. - 192 с.

8. Лотман Ю. М. Труды по знаковым системам / Ю. М. Лотман. - Тарту : Тартусский университет, 1970. - 425 с.

9. Любовь к трем апельсинам : журнал доктора Дапертутто. - 1914. - № 1.

10. Марков П. А. О театре : в 4 т. / П. А. Марков. - М. : Искусство, 1974.

11. Мейерхольд В. Э. Статьи, письма, беседы, речи : в 2 т. [сост. А. В. Февральский] ; общ. ред. и вступ. статья Б. И. Ростоцкий / В. Э. Мейерхольд. - М. : Искусство, 1968.

12. Орлов В. Н. Пути и судьбы / В. Н.Орлов. - М ; Л. : Советский писатель, 1963. - 668 с.

13. Фукс Г. Революция театра : история Мюнхенского Художественного театра / Г. Фукс. - СПб. : Изд-во «Грядущий день», 1911. $-288 \mathrm{c}$.

14. Шах-Азизова Т. К. Чехов и западноевропейская драма его времени / Т. К. Шах-Азизова. - М. : Наука, 1966. $151 \mathrm{c}$.

\section{References}

1. Arhangelskiy, A. (1912-1913). Muzyika i ritm stsenicheskogo deystviya // Maski. - M. - № 6 [in Russian].

2. Belyiy, A. (1911). Arabeski. - M. : Musaget, 501 [in Russian].

3. Berkovskiy, N. Ya. (1969). Literatura i teatr : Stati raznyih let. - M. : Iskusstvo, 639 [in Russian].

4. Bryusov, Val. (1975). Sobr. soch. : v 7 t. - M. : Hudozhestvennaya literatura. - T. 6, 389 [in Russian].

5. Volkonskiy, S. (1912). Chelovek na stsene. - Spb. : Apollon, 182 [in Russian].

6. Ivanov, Vyach. (1916). Borozdyi i mezhi Opyita esteticheskie i kriticheskie. - M. : Musaget, 244 [in Russian].

7. Kugel, A. R. (1922). Utverzhdenie teatra. - L. : Teatr i iskusstvo, 192 [in Russian].

8. Lotman, Yu. (1970). M. Trudyi po znakovyim sistemam. Tartu : Tartusskiy universitet, 425 [in Russian].

9. Lyubov $\mathrm{k}$ trem apelsinam : zhurnal doktora Dapertutto. 1914. - № 1.

10. Markov, P. A. (1974). O teatre : v 4 t. - M. : Iskusstvo [in Russian].

11. Meyerhold, V. E. (1968). Stati, pisma, besedyi, rechi : v 2 t. [sost. A. V. Fevralskiy] ; obsch. red. i vstup. statya B. I. Rostotskiy. - M. : Iskusstvo [in Russian].

12. Orlov, V. N. (1963). Puti i sudbyi. - M ; L. : Sovetskiy pisatel, 668 [in Russian].

13. Fuks, G. (1911). Revolyutsiya teatra : istoriya Myunhenskogo Hudozhestvennogo teatra. - SPb. : Izd-vo «Gryaduschiy den», 288 [in Russian].

14. Shah-Azizova, T. K. (1966). Chehov i zapadnoevropeyskaya drama ego vremeni. - M. : Nauka, 151 [in Russian]. 